\title{
The Analysis Technical Performance of Longline Fishing Vessel in PPI Palabuhanratu, Sukabumi, West Java
}

\author{
Shanty Manullang 1,a,*, T.D. Novita ${ }^{1, b}$ and Ayom Buwono ${ }^{2, c}$ \\ ${ }^{1}$ Department of Naval Architecture, Faculty of Marine Technology, Darma Persada University, \\ Jakarta, Indonesia \\ ${ }^{2}$ Department of Marine Engineering, Faculty of Marine Technology, Darma Persada University, \\ Jakarta, Indonesia \\ a.Shanty_manullang@ftk.unsada.ac.id,b.theresiana_dwirina_novita@ftk.unsada.ac.id, \\ c.abuwono.energi@gmil.com \\ *corresponding author
}

Keywords: $\quad$ Performance, Long Line, Main Dimension, and Stability

\begin{abstract}
Information on technical variability of fishing vessels is expected to describe the dimensions and shapes of the fishing vessel. Therefore, it is necessary to conduct study related to the number and technical characteristics of the fishing vessels in a particular area. This study was conducted in PPI Palabuharatu, Sukabumi, West Java. The purpose of this study is to calculate the number of the longline fishing vessel and identify its variabilities and Performance in PPI Palabuhanratu, Sukabumi, and West Java. Therefore, census was employed as the methodology of this study. Data collected consisted of the number of longline fishing vessel and its main dimension and calculated in numeric analysis. The results of the Technical Performance of Longline Fishing Vessel analysis were then compared with the of minimum standard value derived from criteria of Inamura and Yamazaki (1968) and the research of Iskandar and Pujiati (1995). Based on the result, it was that the number of longline fishing vessel was 30 units and the value of main dimension was below in Inamura standart for $\mathrm{L} / \mathrm{B}$ but in $\mathrm{L} / \mathrm{D}$ and $\mathrm{B} / \mathrm{D}$ upper from Inamura. In coefficient of fineness Longline fishing vessel are below from the criteria of Inamura.
\end{abstract}

\section{Introduction}

The fishing vessel are typically designed with a specific purpose. That purpose is to locate, catch, and preserve fish while the vessel on the sea. The planned operations of a vessel are depending on the overall size of the vessel, the arrangement of the deck, carrying capacity, as well as the machinery and types of equipment that supported by the vessel. Due to the differences in ocean characteristic, there is a wide range of types and styles of fishing vessels around the world.

The construction of the fishing vessel is designed based on fishing gear operational procedure and the area condition where the vessel is operated. The Longline can be recognized easily as its performance is similar to battle ship, but it is completed with store room for keeping the fishing gear in back, and having a deck in the mid ship area (Simorangkir in Ardani 1995). The 
performance of fishing vessel is based on its main dimension, the comparison of its main characters and the coefficient of the ship form (Fyson, 1985). The characteristics measured in the fishing vessel consist of the ship length (L), bouded (B), depth (D) and draft (d). The concurrence of the dimension ratio will affect the capability of the vessel, as it affects the vessel's resistance, vessel's longitudinal strength (L/D) and the vessel stability (B/D) (Fyson, 1985).

The longline is esspecially designed to catch tuna, and its construction enable it to reach the swim depth of the fish (swimming layer) and it is suitable to be operated in territorial water, ZEEI 200 mile. In this area, the potency of tuna fish is estimated to be 258,8 thousand tons per year (Anonymous, 1983). Increasing the potency of tuna fish in this area is became a challenge for us to manage nad expoit it properly.

The long liner is one of the most important factor in tuna fish catching and thus it is very important in supporting the economic life in PPI Palabuhan Ratu .

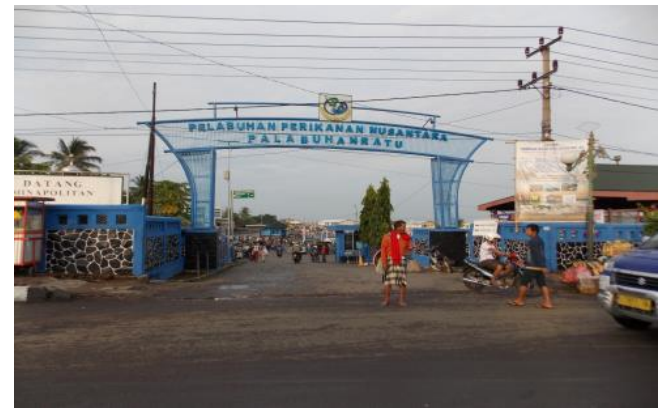

Figure 1: Nusantara Fishing Harbor, Palabuhanratu

The Knowledge of the ship design development and the ship performance is important in manufacturing the good fishing vessel. Information on technical variability of the fishing vessel, including the main dimension and shape of the vessel is rare. Therefore, it is necessary to conduct a study on the number and technical characteristic of the fishing vessel available in the PPI Pelabuhanratu, Sukabumi, West Java.

\section{Methodology}

There are 2 types of data collected in this study. The secondary data, which is the data related to territorial water condition are categorized as secondary data and they were collected by distributing questionnaires to respondent. While the principal dimensions of the fishing Vessel were categorized as the primary data and they were obtained from the Fishing Port. The data on the vessel dimension are presented in Table 1.

Data Analysis. The data of fishing vessel are collected and processed through numerical analysis method, in order to calculate the naval architecture (hydrostatic parameter), by using the excel program. While the data of vessel dimension were analysis using an AutoCAD software. The analysis results were then compared with the data compared to Inamura (1968) as a standard.

\section{Result}

Measurement of the main dimensions of the vessel is very important to analyze the value at L/B, L/D and B/D which can affect to the strength, speed and stability.

One of the simplest parameters that can be used to determine the size of the ship to be built is the ratio of the main dimension. The value of the main dimension ratio is the simplest and simplest 
approach to determine the size of the vessel to suit the fishing equipment to be used and the catching area to be targeted (Susanto, 2011).

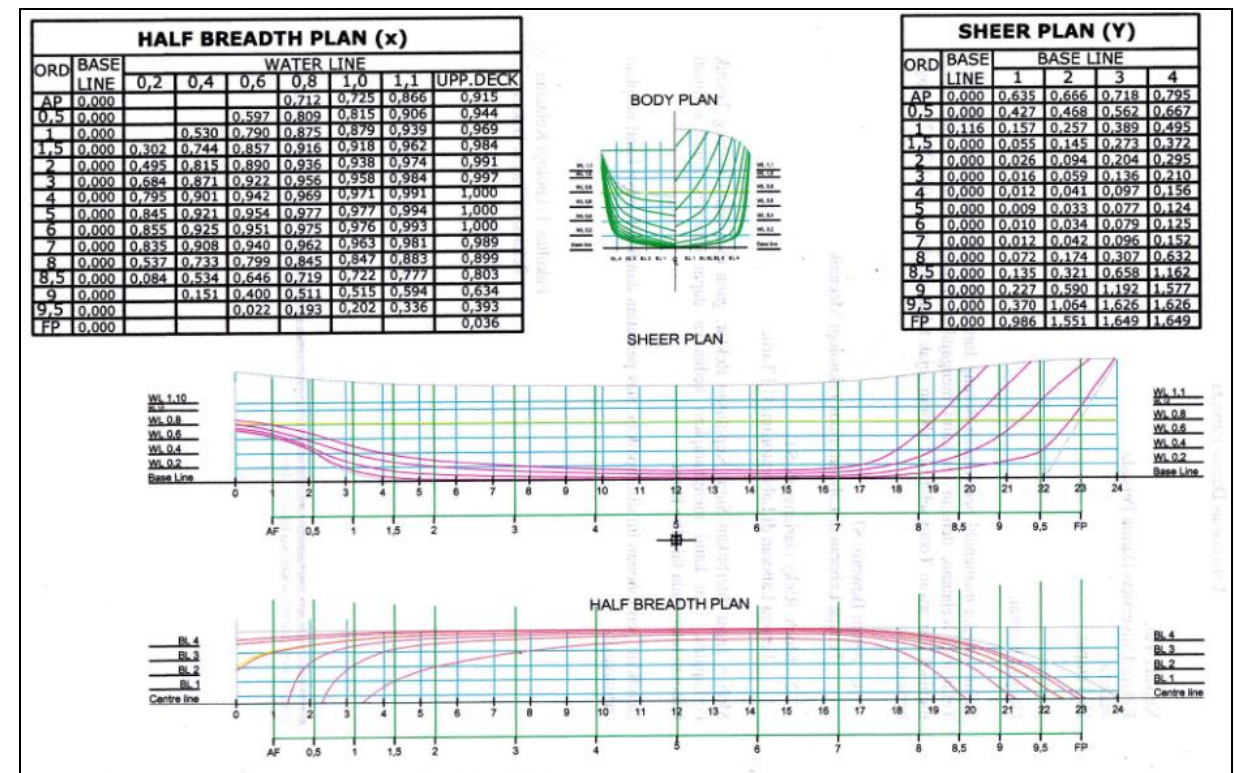

Figure 2: The Longline vessels lines plan

Table 1: The principal dimension of longline fishing vessel in the study area (L $15-20 \mathrm{~m})$

\begin{tabular}{|l|l|c|c|c|}
\hline \multirow{2}{*}{ No } & \multirow{2}{*}{ Longliner Name } & \multicolumn{3}{|c|}{ Principal Dimension } \\
\cline { 1 - 4 } & & L/B & L/D & B/D \\
\hline 1 & Margo Abadi & 3,73 & 11,44 & 3,06 \\
2 & Cahaya bahari_01 & 3,35 & 14,61 & 4,37 \\
3 & KM Cakra Bahari & 3,62 & 12,40 & 3,43 \\
4 & Gunawan 28 Jaya_1 & 3,70 & 10,30 & 2,79 \\
5 & Hasil Laut_32 & 3,07 & 8,17 & 2,66 \\
6 & Anita Jaya_XI & 3,85 & 9,25 & 2,40 \\
7 & Trans Bahari_3 & 2,84 & 10,06 & 3,54 \\
8 & Anna Rizky_7 & 3,95 & 9,67 & 2,44 \\
9 & Ateria Daya Mulia & 3,60 & 11,25 & 3,13 \\
10 & Maju Jaya & 4,18 & 11,75 & 2,81 \\
11 & Maju Jaya 1 & 4,16 & 11,00 & 2,65 \\
\hline
\end{tabular}

Table 2: The principal dimension of longline fishing vessel in the study area (L $20-25 \mathrm{~m}$ )

\begin{tabular}{|c|l|c|c|c|}
\hline \multirow{2}{*}{ No } & \multirow{2}{*}{ Longliner Name } & \multicolumn{3}{|c|}{ Principal Dimension } \\
\cline { 3 - 5 } & & L/B & L/D & B/D \\
\hline 1 & Lingsar_06 & 3,50 & 11,33 & 3,24 \\
2 & Mitra jaya_V & 3,64 & 11,01 & 3,02 \\
3 & Mahkota & 4,72 & 9,76 & 2,07 \\
& Abadi_39 & & & \\
4 & Koyong Jaya_V & 3,94 & 18,67 & 4,74 \\
5 & Berkah Sahabat & 3,55 & 8,39 & 2,37 \\
\hline
\end{tabular}


Data presented in Table 1 and 2 and the graphs shown that the ships in the study area variability in its dimension.

According Iskandar (2007) designed a fishing Vessel made of wood, the main concern of the dimension between lines over all (Loa), breath (B), and depth of the vessel (D). The comparison of these dimensions is an initial parameter describing the shape and type of vessel.

One of the simplest parameters that can be used to determine the size of the ship to be built is the ratio of the main dimension. The value of the main dimension ratio is the simplest and simplest approach to determine the size of the vessel to suit the fishing equipment to be used and the catching area to be targeted (Susanto, 2011).

\subsection{INAMURA Standard}

Further classification of the long liner is based on its target catching area, in the water column (bottom or midwater) or their processing capabilities (wet-fish, freezer, and factory). The result of the principal dimension ratio calculation, the L/B, L/D and D/B are presented at Tables 1 and 2.

The data will be classification based on two categories:

a. Vessel length $15-20 \mathrm{~m}$

b. Vessel length $20-25 \mathrm{~m}$

\subsection{Vessel Length $15-20 \mathrm{~m}$}

Table 3: Comparison of the principal dimension of longline vessel (L15-20 m) to Inamura Standard

\begin{tabular}{|c|l|c|c|c|c|c|c|}
\hline \multirow{2}{*}{ No } & \multirow{2}{*}{ Longliner Name } & \multicolumn{3}{|c|}{ Principal Dimension } & \multicolumn{3}{c|}{ Inamura Standard } \\
\cline { 3 - 8 } & & L/B & L/D & B/D & L/B & L/D & B/D \\
\hline 1 & Margo Abadi & 0,1757 & 0,4889 & 0,1292 & 0,1736 & 0,3681 & 0,1042 \\
\hline 2 & Cahaya bahari_01 & 0,1493 & 0,6257 & 0,1924 & - & - & - \\
\hline 3 & KM Cakra Bahari & 0,1681 & 0,5278 & 0,1549 & 0,2153 & 0,4097 & 0,1042 \\
\hline 4 & Gunawan 28 & 0,1736 & 0,4375 & 0,1382 & & & \\
\hline 5 & Jaya_1 & 0,1299 & 0,3451 & 0,1292 & & & \\
\hline 6 & Anita Jaya_XI & 0,1840 & 0,3924 & 0,1111 & & & \\
\hline 7 & Trans Bahari_3 & 0,1417 & 0,4208 & 0,1625 & & & \\
\hline 8 & Anna Rizky_7 & 0,1910 & 0,4215 & 0,1139 & & & \\
\hline 9 & Ateria Daya Mulia & 0,1667 & 0,4757 & 0,1340 & & & \\
\hline 10 & Maju Jaya & 0,1792 & 0,5104 & 0,1396 & & & \\
\hline 11 & Maju Jaya 1 & 0,1778 & 0,4583 & 0,1285 & & & \\
\hline
\end{tabular}

The principal dimension ratio of fishing vessels should be well known as these values have an effect the stability ship resistance. According to Iskandar and Pujiati (1995) value of ratio of L/B and L/D for the long liner (static gear) is bigger than that of other type of ship, as the long liner need high stability during its operation, whether in setting and also hauling times, because the speed of the vessel is zero $(\mathrm{v}=0)$ during this operation. 


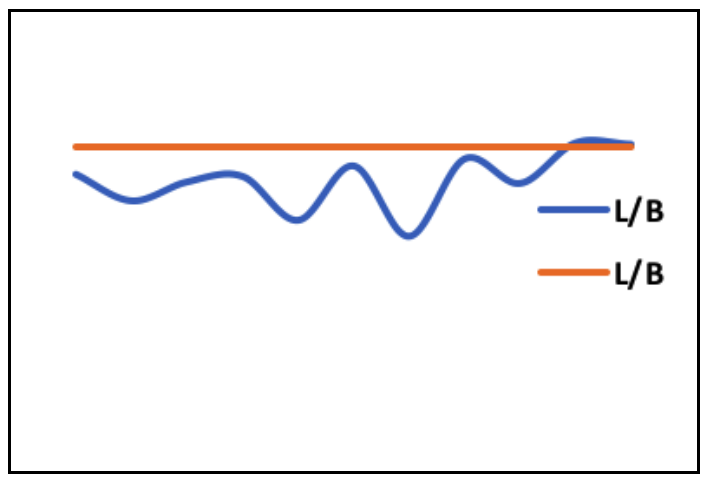

Figure 3: Comparison of the pincipal dimension (L/B) of longline vessel to Inamura standart

Palembang et al. (2013) Affirms that the value of L/B are used to analyze the maneuverability and the velocity of a vessel, the lower the value of L/B the better the vessel's maneuverability. While the maneuverability improves, the vessel's velocity decreases. This shows that long line vessels in PPI Palabuhan Ratu have a good stability, but the resistance on the vessel's body is quite huge that in the end it affects the vessel's velocity. The long line vessel needs a bigger L/B value so it can increase the vessel's velocity. The L/B value of the vessels that being researched were very different, but there were only 2 vessels that match Inamura standard.

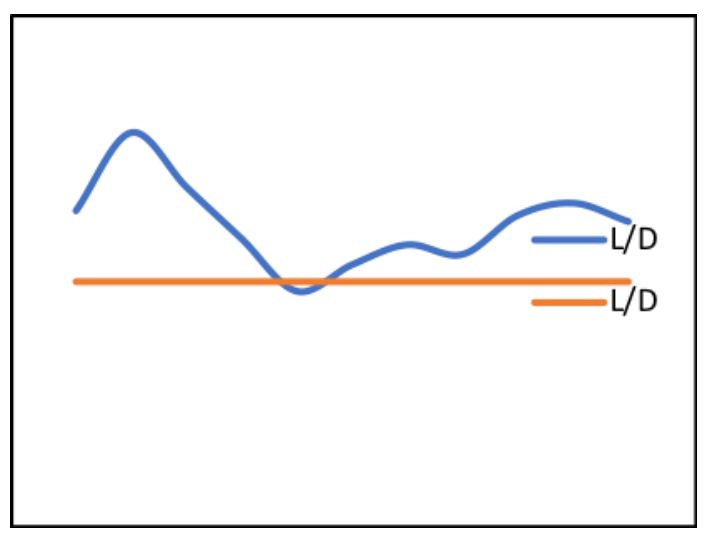

Figure 4 : Comparison of the pincipal dimension (L/D) of longline vessel to Inamura standart

The L/D value affect the vessel's longitudinal strength which are needed so that the vessel's is strong enough, even though the vessel's is up against bad weather conditions which normally can cause fractures on the vessel's hull. The existing of resistance makes the operation velocity of the vessel decreases, thus to overcome the resistance, it is needed to provide some additional thrust power so it can get through against the sea with certain velocity.

The L/D value on long line vessel is far greater from the standard provided which then makes the longitudinal strength of the vessel is higher than it supposed to be. 


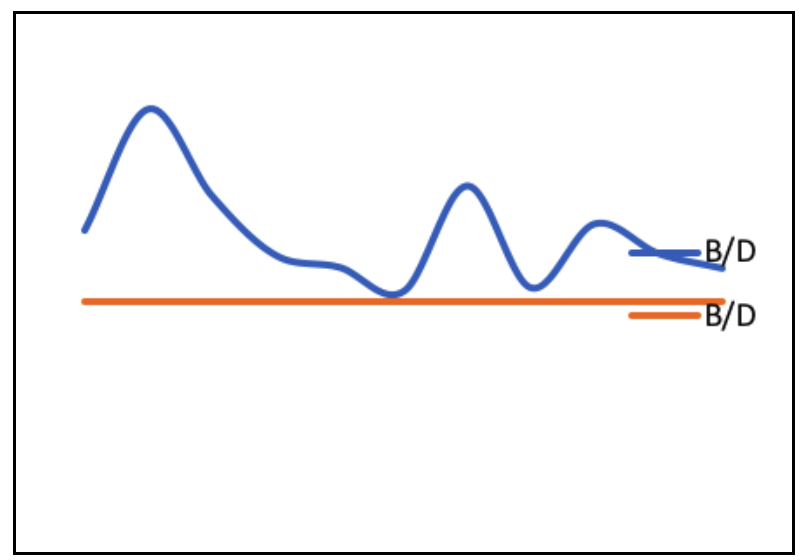

Figure 5: Comparison of the principal dimension (B/D) of longline vessel to Inamura standard

The range of the $\mathrm{B} / \mathrm{D}$ value that being researched is $2.84-4.37$. Values of each vessel are so different from one to another and there is no vessel that match to Inamura Standard. All the B/D value is bigger than the standard.

\subsection{Vessel Length $20-25 \mathrm{~m}$}

Tabel 4: Comparison of the principal dimension of longline vessel (L 20 - 25m) to Inamura Standard

\begin{tabular}{|c|l|c|c|c|c|c|c|}
\hline \multirow{2}{*}{ No } & \multirow{2}{*}{$\begin{array}{l}\text { Nongliner } \\
\text { Name }\end{array}$} & \multicolumn{3}{|c|}{ Principal Dimension } & \multicolumn{3}{|c|}{ Inamura Standard } \\
\cline { 2 - 8 } & L/B & L/D & B/D & L/B & L/D & B/D \\
\hline 1 & Lingsar_06 & 03.50 & 11.33 & 03.24 & 04.30 & 08.50 & 0,104 \\
\hline 2 & Mitra jaya_V & 0,169 & 11.01 & 03.02 & - & - & - \\
\hline 3 & $\begin{array}{l}\text { Mahkota } \\
\text { Abadi_39 }\end{array}$ & 0,217 & 0,428 & 02.07 & 0,229 & 09.50 & 02.30 \\
\hline 4 & $\begin{array}{l}\text { Koyong } \\
\text { Jaya_V }\end{array}$ & 0,190 & 0,797 & 0,218 & & & \\
\hline 5 & $\begin{array}{l}\text { Berkah } \\
\text { Sahabat }\end{array}$ & 03.55 & 08.39 & 02.37 & & & \\
\hline
\end{tabular}

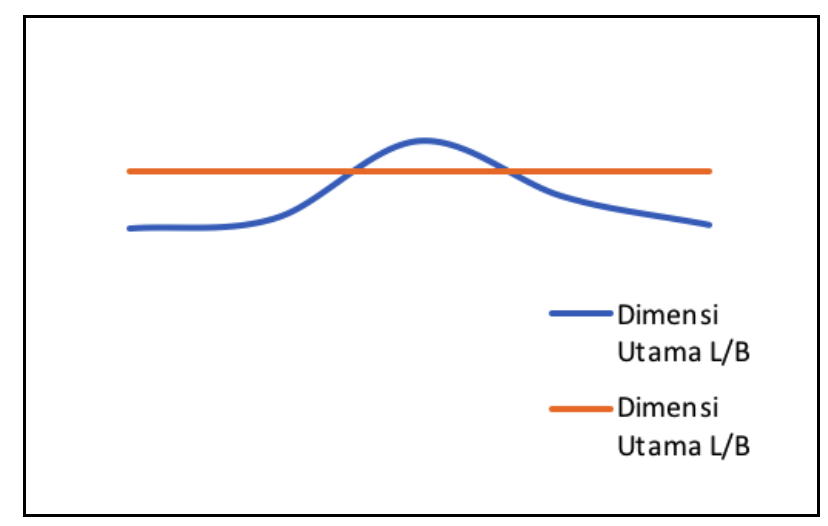

Figure 6: Comparison of the pincipal dimension (L/B) of longline vessel to Inamura standart 
From the acquired data, there is only 1 (one) ship meets the Inamura standard. This shows that the vessels were built without a proper design, which then affect the vessel's maneuverability.

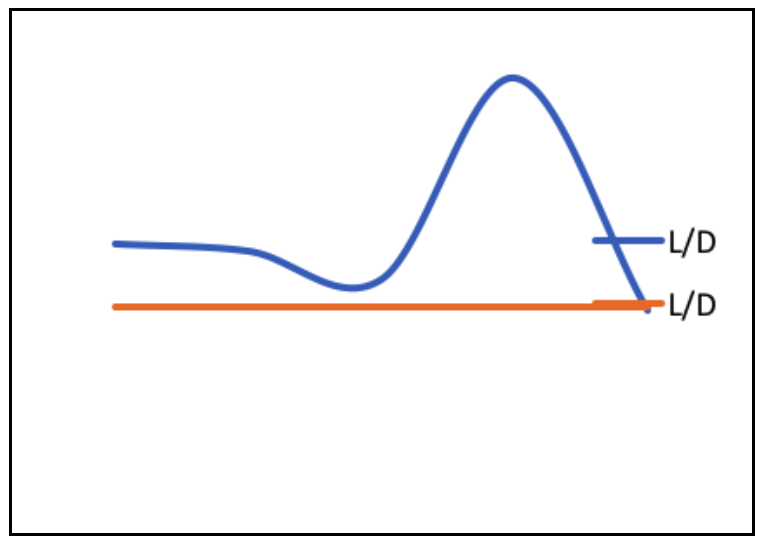

Figure 7: Comparison of the principal dimension (L/D) of longline vessel to Inamura standard

The L/D value is far greater than the Inamura Standard, provided which then makes the longitudinal strength of the vessel is higher than it supposed to be. The L/D value are ranged from 8.39 to 18.67 .

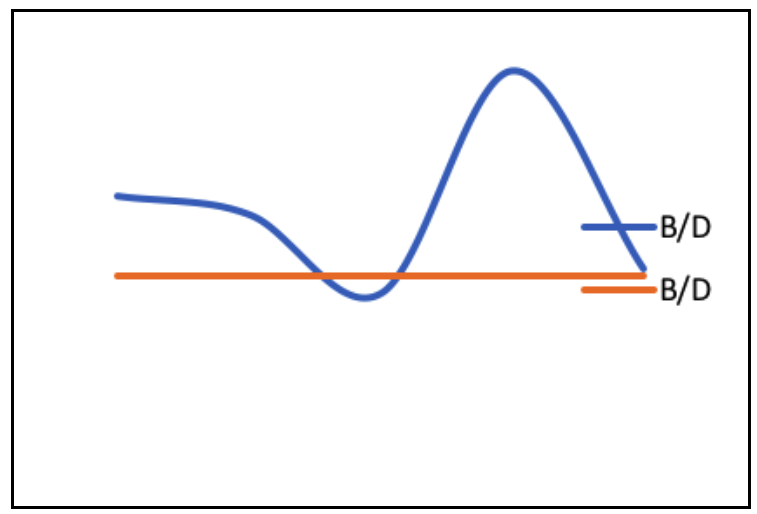

Figure 8: Comparison of the principal dimension (B/D) of longline vessel to Inamura standard

The range of the $\mathrm{B} / \mathrm{D}$ value that being researched is $2.07-4.74$. The $\mathrm{B} / \mathrm{D}$ values of each vessel are so different from one to another and all the vessel not match to Inamura standard.

Long line vessel needs a good stability especial during the process of hauling because the vessel will lean on one side only. Novita et al. (2014) affirms that the bigger B/D value the better the stability and the maneuverability of the vessel will be. Mulyanto et al. (2010) affirms that a vessel needs high stability because of the hauling process is only on one side of the vessel's hull which makes the vessel loads focused on one side only and while the nets is being hauled onto the vessel, the vessel will tilt.

\section{Conclusions}

1. The value of main dimension was below in Inamura standard for $\mathrm{L} / \mathrm{B}$ it means that longline vessels in PPI Palabuhan Ratu have a good stability, but the resistance on the vessel's body is quite huge that in the end it affects the vessel's velocity.

2. The $L / D$ value on long line vessel is far greater from the standard provided which then makes the longitudinal strength of the vessel is higher than it supposed to be. 
3. It is important to redesign the Tuna long line fishing vessel and technical characteristics especially in PPI Palabuhanratu.

\section{References}

[1] Ayodhyoa. 1972. An recognition Fishing Gear. Agriculture Bogor Institute Fishery Faculty

[2] Fyson J. 1985. Desingn Of Small Fishing Vessel. Fishing News Books Ltd. England

[3] Guritno et all,2016. Main Dimensions Characteristic of Purse Seine Fishing Vessel in Lempasing Coastal Fishing Port Lampung Province, Fisheries and marine journal, Vol. 6 No. 1 : 21-30.

[4] Iskandar, B.H. and Pujiati Sri. 1995. Technical performance of Fishery Ship [in] Territorial Water Indonesia. Exploiting the reseource of Fishery Majors. IPB.

[5] Iskandar BH. 2007. Static and dynamic stability on Training Ship Stella Maris. Buletin PSP. No. 16(1): 31 -49.

[6] Mulyanto RB, Wahyono A, Kertorahardjo RSP. 2010. Fishing Vessel (Dimension and Calculation). Semarang : Balai Besar Pengembangan Penangkapan Ikan (BPPT).

[7] Novita Y, Martiyani N, Ariyani RE. 2014. The quality of stability on Payang Palabuhanratu ship based on cargo distribution. Ipteks Journal PSP 1 (1).

[8] Paroka, D. and Umeda N. ( 2007): Effect Of freeboard and metacentric height on capsizing probability of purse seiners in beam ace, Journal Of Marine Science and Technology, Vol. 12 No 3. Matter 150 - 159

[9] Palembang S, Alfret L, Fransisco PTP. 2013. Research on Design and Build of Multifuction Fiberglass Fishing Vessel 13 GT in Shipyard owned by CV. Cipta Bahari Nusantara Minahasa North Sulawesi. Journal of Education and Fishing Technology 1 (3).

[10]Susanto. A, B.H.Iskandar And M.Imron. 2011. Static Stability [of] Ship Static Gear [in] Palabuhanratu ( Case Study [of] KM PSP 01). Marine Fisheries- Technological Journal And the Sea Fisher Management. Vol.2, No.1, May 2011. ISSN : 2087 - 423 